Original scientific paper

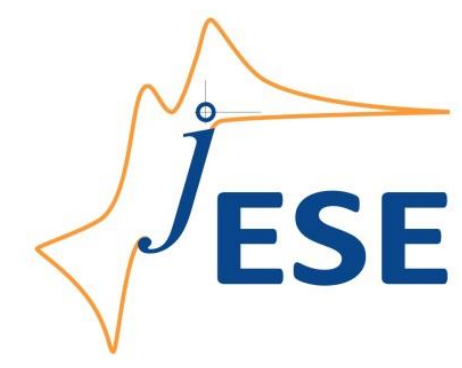

Open Access : : ISSN 1847-9286

www.jESE-online.org

\title{
An improved method of water electrolysis - effect of complexing agent
}

Seetharaman Swaminathan*,**, Balaji Rengarajan*, Ramya Krishnan*, ${ }^{*}$, Kaveripatnam Samban Dhathathreyan*, Manickam Velan**

*Centre for Fuel Cell Technology, International Advanced research Centre for Powder Metallurgy and New Materials( ARCI), II Floor, IIT-M Research Park, No.6 Kanagam road, Taramani, Chennai- 600 113, India

**Department of Chemical Engineering, A.C. College of Technology, Anna University, Chennai-600 025, India

${ }^{\otimes}$ Corresponding Author: ramya.k.krishnan@gmail.com,Fax: +91-44-66632702

Received: May 17, 2016; Revised: July 1, 2016; Accepted: July4, 2016

\begin{abstract}
The present work investigates the efficiency of an alkaline water electrolysis process in the presence of a complexing agent like citric acid (CA) when added directly into the electrolyte during the electrolytic process. High surface area nickel electrodes prepared by electrodeposition technique were used as the electrode to evaluate the efficiency of the oxygen evolution reaction (OER) by the polarization measurements and cyclic voltammetry. The quantity of the complexing agent $C A$ in the electrolyte was varied from 0-1 wt. \%. An increase in the current density of about $25 \%$ resulted at a temperature of $30{ }^{\circ} \mathrm{C}$ in the presence of $0.2 \mathrm{wt}$. \% of $\mathrm{CA}$ at $1.0 \mathrm{~V}$ vs. $\mathrm{Hg} / \mathrm{HgO}$. CA was found to improve performance by forming a complex with the alloy electrode and by formation of the high surface area catalyst for efficient OER.
\end{abstract}

\section{Keywords}

Citric acid; Alkaline water electrolysis; Oxygen evolution reaction; Complexing agent

\section{Introduction}

Clean energy is considered as the solution to world's increasing energy demand and to concerns regarding pollution and contamination. Hydrogen is important energy alternatives as its combustion product is only water. Water electrolysis is the best technology for producing hydrogen and oxygen with no resulting greenhouse gas emissions [1-3]. The energy required for production of hydrogen by electrolytic method is very high (4.5-5 $\mathrm{kWh} \mathrm{N} \mathrm{m}^{-3}$ of $\mathrm{H}_{2}$ ) in most industrial electrolyzers. Alkaline 
water electrolysis (AWE) offers the advantages of the use of non-noble metal catalysts, ease of manufacturing and scalability. Therefore, research on suitable catalyst materials and methods for modifying the electrodes to improve efficiency of water electrolysis techniques are always being carried out. Efficiency in electrolysis can be improved by reducing the cell voltage through the use of catalysts with increased surface area or by changing the nature of the overpotential of the reaction. In AWE anodic overpotential is a major factor that limits the efficiency and hence is researched frequently [4-6]. Ni based electrodes, being less corrosive in alkaline solution, offer low cost solution despite its higher overpotential in alkaline solutions when compared to costly $\mathrm{RuO}_{2}$ and $\mathrm{IrO}_{2}$ based catalyst used in acidic media [7]. Further, it has been found that incorporation of zinc and sulphur in the nickel electrode increases surface area and catalytic activity, lowers overvoltage and helps in increasing the current density by removal of the gas bubbles from the electrode surface [8].

Citric acid (CA) is a chelating agent often used for depositing metals at a controlled rate in electroplating and electroless plating operations. It is also used to buffer the $\mathrm{pH}$ of the plating bath. The effects of additives in the electroless nickel deposition process have been studied by electrochemical analysis $[9,10]$. It has been shown that the additives significantly improved the deposition rate and helped in forming finer grain structure during the plating process. The importance of additives such as boric acid, citric acid and ascorbic acids in influencing the electrodeposition of nickel alloys was described by Kieling [11]. It was shown that complexing agents influence the kinetics of powder electrodeposition, as well as the morphology of the Ni powders. According to the conclusion of the authors finer powders were produced in the presence of citric acid than those obtained with oxalic acid. A study on organic additive, tri sodium citrate as a stabilizing agent reveals that they can be used for structure related factors to control the nucleation, growth and alignment of crystal phases [12,13].

Nikolić et al. [14] have shown that alkaline electrolytic hydrogen production can be made efficient ( $\sim 15 \%$ ) by the addition of activating compounds of tungsten and cobalt in the ionic and complex form into the electrolyte $(6 \mathrm{M} \mathrm{KOH})$ during electrolytic process. Additions of ionic activators were found to increase surface area, porosity and performance due to the synergistic effect of the two different metals on the surface of the electrode. The effect of ionic activators and complexes in alkaline water electrolysis has been emphasized by improved performance in the presence of molybdate, chromate and cobalt based compounds $[15,16]$. The ability of citric acid to form complexes with $\mathrm{Ni}$ is very well established. It has been used to decrease the precipitation of $\mathrm{Ni}$ as hydroxides thus stabilizing it in the electrolyte. It has been used in both the electroless and electrodeposition of $\mathrm{Ni}$ and its alloys $[17,18]$. It was hence decided to study the effect of this stabilizer during the electrolysis of water by adding it to the electrolyte, i.e. to study whether the $\mathrm{Ni}$ citrate complex formed will act similar to the ionic activator and improve the efficiency of the electrolytic process. In the present system the activator is formed in situ from the electrode and the complexing agent in the solution compared to those in the literature where the metal complexes are externally added. A systematic study on OER has been carried out by varying the concentration of citric acid in the electrolyte between 0 and $1 \%$ by weight.

\section{Experimental}

\section{Materials}

Nickel sulphate (Merck), nickel chloride (Merck), zinc sulphate (Merck), ammonium nickel sulfate (Merck), sodium thiocyanate (Fisher), potassium hydroxide (Merck), citric acid (Merck) and other 
chemicals were all used as received. Ni mesh (procured from Champion Manufacturing Co, India with $0.10 \times 0.32 \times 0.20 \mathrm{~mm}$ nominal thickness, long diagonals of the diamond and strand width respectively) of area $9.0 \mathrm{~cm}^{2}$ size were used for preparation of the electrodes.

\section{Electrode fabrication}

The surface of nickel mesh was electrochemically cleaned before electroplating using the bath solution containing nickel chloride $\left(240 \mathrm{~g} \mathrm{~L}^{-1}\right)$ and conc. $\mathrm{HCl}\left(125 \mathrm{ml} \mathrm{L}^{-1}\right)$. A plating current density of $50 \mathrm{~mA} \mathrm{~cm}{ }^{-2}$ was used for cleaning. The plating bath consisting of nickel (II) sulphate $\left(70 \mathrm{~g} \mathrm{I}^{-1}\right)$, ammonium nickel sulfate $\left(40 \mathrm{~g} \mathrm{~L}^{-1}\right)$, zinc sulphate $\left(35 \mathrm{~g} \mathrm{~L}^{-1}\right)$ and sodium thiocyanate $\left(12 \mathrm{~g} \mathrm{~L}^{-1}\right)$ were used for plating. Electrodes were prepared by the pulse electrodeposition technique as mentioned in our previous paper with a pH of 5-6, a current density of $40 \mathrm{~mA} \mathrm{~cm} \mathrm{~cm}^{-2}$ and duty cycle of $40 \%$ under the influence of ultrasonic vibration [19]. Once the electrodeposition was concluded, the electrodes were treated with $28 \mathrm{~g} \mathrm{~L}^{-1}$ of $\mathrm{KOH}$ to leach out excess zinc to give a porous electrode having a high surface area.

\section{Cell frame-up}

Electrochemical measurements were carried out using a Solartron analytical potentiostat/galvanostat 1400 cell test system in a small undivided beaker cell (volume $50 \mathrm{~cm}^{3}$ ). As prepared nickel alloy electrode (working electrode), large area platinum gauze (counter electrode) and $\mathrm{Hg} / \mathrm{HgO}$ reference electrode in $1 \mathrm{M} \mathrm{NaOH}$ were used for the study. The area of the electrode was $9 \mathrm{~cm}^{2}$ and $30 \% \mathrm{KOH}$ solution to which CA between 0 and $1 \mathrm{wt}$. \% has been added was used as the electrolyte. Figure 1 shows the cell set up used for testing of the electrodes of the present study.

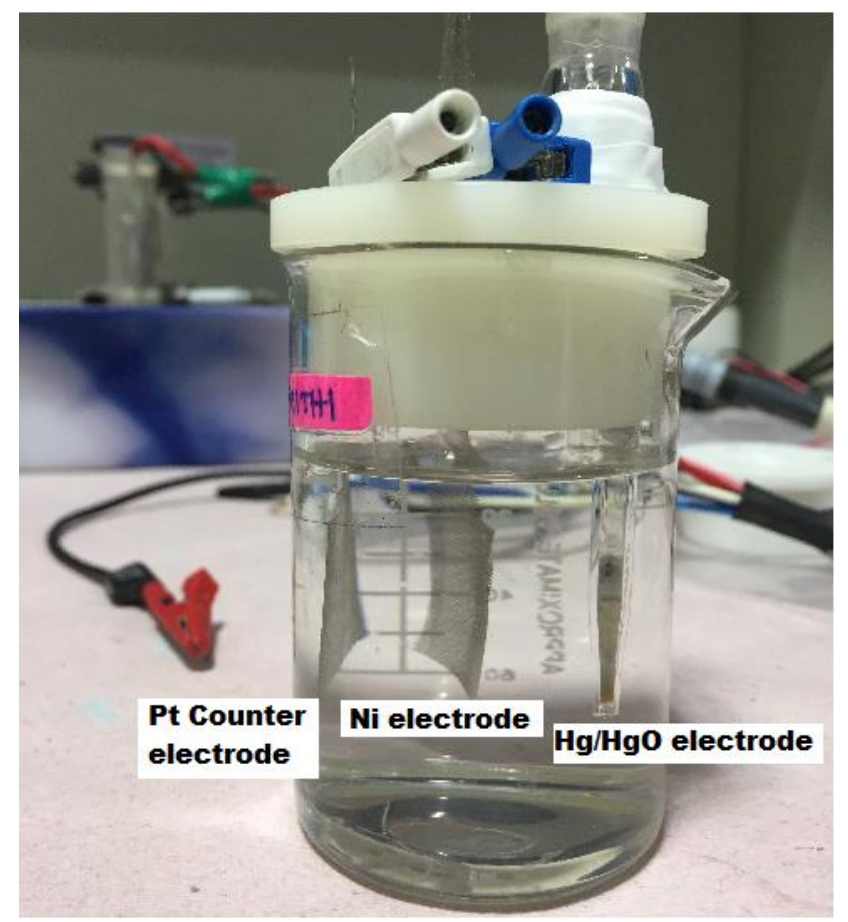

Figure 1. Three electrode cell set up used for electrochemical characterization

\section{Electrode characterization}

The surface morphology of the electrodes was studied using Hitachi SU1500 Scanning Electron Microscopy (SEM). Energy dispersive analysis of X-ray (EDAX) using Hitachi 4300 was used to study the composition of metals on the electrode. Rigakuminiflex X-Ray diffraction (XRD) with CuK $\mathrm{K}_{\alpha}$ 
$(\lambda-0.154 \mathrm{~nm})$ radiation was used for $X$-ray characterization of the electrodeposits. Perkin-Elmer system was used to obtain the Fourier Transform Infrared spectra (FT-IR).

\section{Results and discussion}

\section{FT-IR analysis}

Figure 2 shows FT-IR spectra of the nickel electrode with and without the addition of stabilizer. The bands due carboxyl groups of citric acid are present between 1800 and $1300 \mathrm{~cm}^{-1}$. The band at $1721 \mathrm{~cm}^{-1}$ has been ascribed to free COO- group. The band at $1630 \mathrm{~cm}^{-1}$ has been ascribed to the carboxylic group forming intramolecular hydrogen bonds. The band at $1425 \mathrm{~cm}^{-1}$ may be assigned to the bidentate carboxylate anion. For nickel alloy electrode in citric acid spectra, the band around $3450 \mathrm{~cm}^{-1}$ was very broad, due to hydration by water molecule indicating the electrolytes ability to wet the electrode. In spectra without citric acid due to less adsorbed water molecule this peak was small. The bands around 1150 and $650 \mathrm{~cm}^{-1}$ represent the stretching vibrations of the nickel sulphate used for electroplating of nickel [12]. These studies confirm the formation of nickel citrate complex on dipping the electrode in the electrolyte containing CA. Literature studies have shown that upon immersion of a nickel electrode into the solution of aqueous alkali, a film of $\mathrm{Ni}(\mathrm{II})$ oxide species ( $\alpha$ $\left.\mathrm{Ni}(\mathrm{OH})_{2}\right)$ is formed spontaneously [20]. This on ageing dehydrates and gets converted into $\beta-\mathrm{Ni}(\mathrm{OH})_{2}$. The electroprecipitation of this oxide forms $\mathrm{Ni}$ plaques and may lead to decrease in performance. On addition of citric acid into the electrolyte $\mathrm{Ni}$ forms citrate complexes that may help in cleaning the surface of the oxide layer. The complexes formed may improve the wetting ability of the electrolyte by decreasing the surface tension of the electrodes.

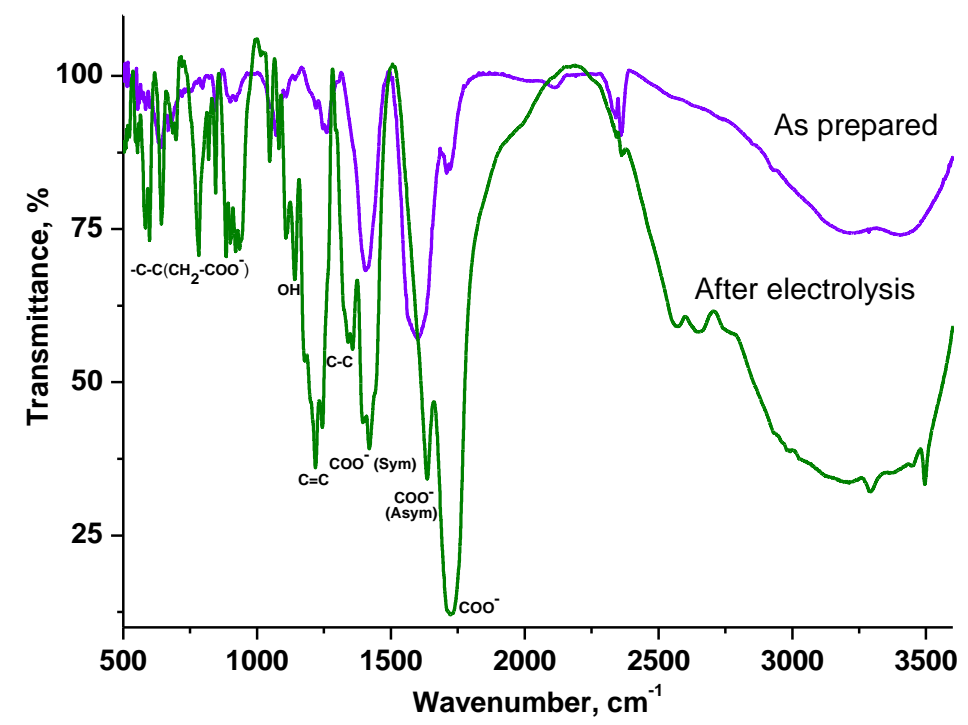

Figure 2. FT-IR Spectra of electrolytic surface: (a) before and (b) after citric acid addition

\section{Effect of variation of $C A$}

Figure 3 shows the polarization curves with the variation in the amount of $C A$ at $30^{\circ} \mathrm{C}$. A current density of $0.40 \mathrm{Acm}^{-2}$ was achieved with $0.1 \mathrm{wt} \%$ addition of CA compared to $0.32 \mathrm{~A} \mathrm{~cm}^{-2}$ achieved without the addition of $\mathrm{CA}$ at $1.0 \mathrm{~V}$ vs. $\mathrm{Hg} / \mathrm{HgO}$ reference electrode. The maximum current density of $0.47 \mathrm{~A} \mathrm{~cm}^{-2}$ was obtained on the addition of $0.2 \% \mathrm{CA}$ at $1.0 \mathrm{~V}$. Further increase in citric acid led to decrease in current density to $0.37 \mathrm{~A} \mathrm{~cm}^{-2}$ at $0.3 \% \mathrm{CA}$ addition. In alkaline solution without CA, $\mathrm{Ni}(\mathrm{OH})_{2}$ precipitates on the surface and gets absorbed on the electrode, passivates the electrode decreasing the kinetics of the reaction. On the addition of $\mathrm{CA}$, formation of $\mathrm{Ni}(\mathrm{OH})_{2}$ on the surface 
decreases and a citrate complex of $\mathrm{Ni}$ is formed resulting in increase of current density. An increase in CA concentration leads to a strong citrate adsorption on the surface reducing the catalytic activity. $\mathrm{Ni}$ citrate particles present on the surface of the electrode may also act as nucleation sites for in situ deposition of metal thereby increasing the activity.

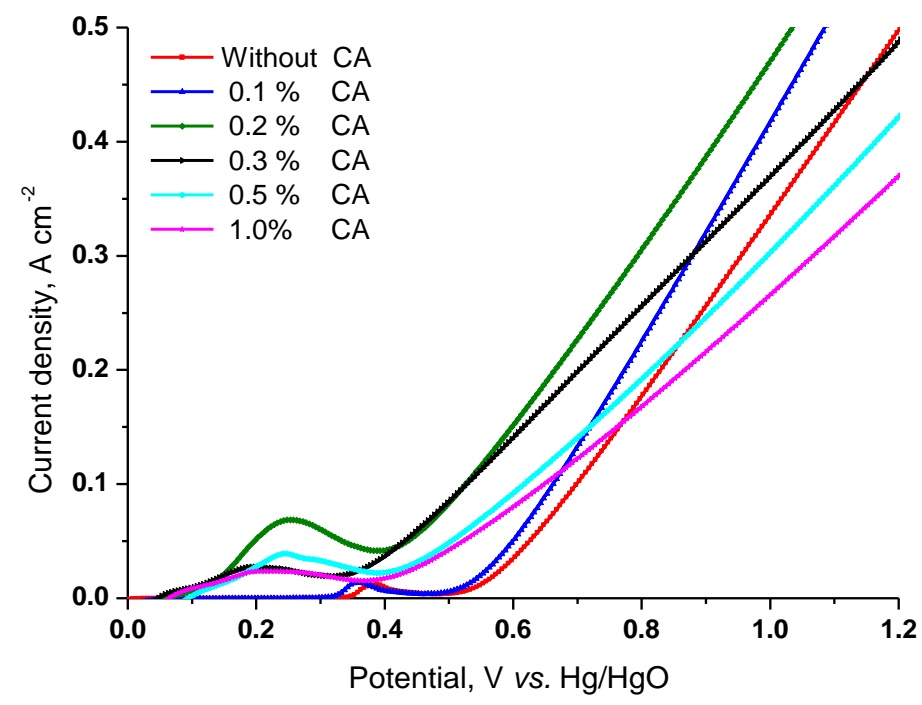

Figure 3. Polarizations curve for alkaline water electrolysis with the different wt.\% of CA at $30^{\circ} \mathrm{C}$.

\section{Cyclic voltammetry studies}

Cyclic voltammograms obtained for the nickel alloy electrodes when scanned between 0 to $0.8 \mathrm{~V}$ vs. NHE at a scan rate of $5 \mathrm{mV} \mathrm{s}^{-1}$ in $30 \% \mathrm{KOH}$ solution are represented in Fig. 4 . The oxide formation on surface of the nickel electrode is represented by the anodic current between the potentials of +0.37 and $+0.58 \mathrm{~V}$ vs. $\mathrm{Hg} / \mathrm{HgO}$. The peak at potential of $+0.16 \mathrm{~V} v$ s. $\mathrm{Hg} / \mathrm{HgO}$ represents the oxide layer reduction upon current reversal. The $\mathrm{Ni}(\mathrm{II})-\mathrm{Ni}$ (III) oxide transformations as represented by peaks acts as electrocatalyst for the OER[13,21]. Of all the additions, 0.2 wt. \% of CA in $30 \%$ potassium hydroxide solution showed the highest area.

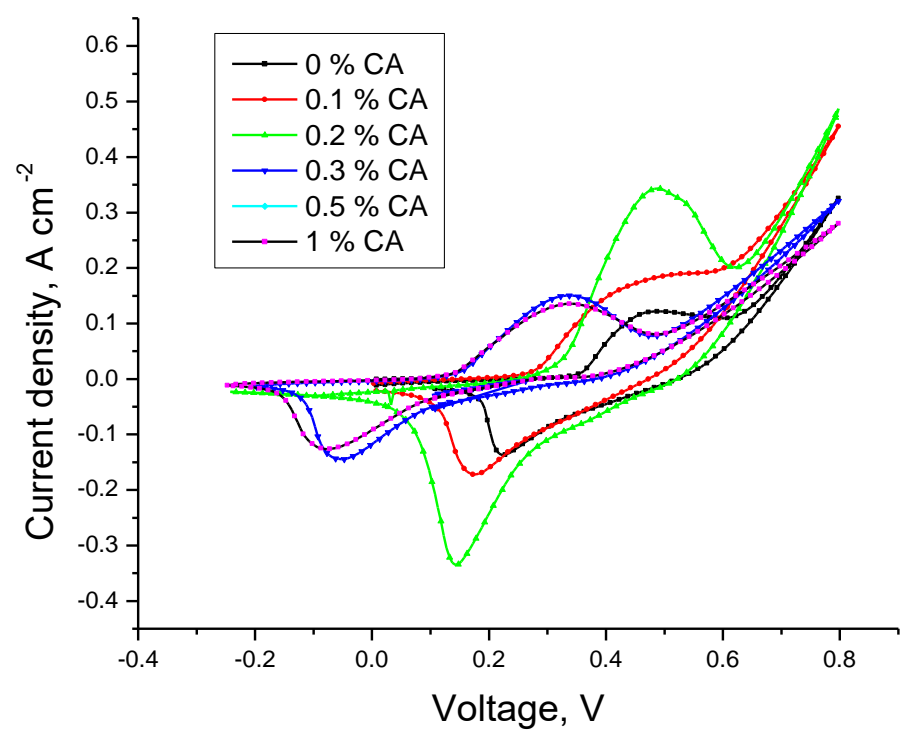

Figure 4. Cyclic voltammograms of nickel alloy electrode with different wt.\% of CA.

The addition of $0.2 \mathrm{wt}$. \% of CA enabled the current to increase more sharply when the potential reaches $\sim 0.52 \mathrm{~V}$. However, upon increasing the citric acid concentration above a $0.2 \mathrm{wt}$. \% a further 
increase was not seen and the curve almost truncated. CA may reduce the surface tension of the electrolyte so the bubbles formed due to evolution of oxygen gas can leave the system easily. At higher concentration of CA, a strong absorption on the surface leads to decrease in catalytic sites and decrease in activity.

\section{Effect of temperature}

Figure 5 a shows the steady state polarization curves of Ni-Zn-S alloy electrode at different temperatures on the addition of citric acid ( $0.2 \mathrm{wt} . \%)$ in alkaline water electrolysis. As can be seen from the polarization curves, performance increases with increase in temperature. $A$ high current density of $0.78 \mathrm{~A} \mathrm{~cm}^{-2}$ was achieved at $1.0 \mathrm{~V}$ and $80^{\circ} \mathrm{C}$. With the introduction of citrate in the system, the overall efficiency increases and overvoltage also decreases for OER. The improved performance may be explained on the basis of an increase in the conductivity of the electrolyte at higher temperatures and also due to increase in catalytic activity with the increase in temperature. Figure $5 b$ gives the long term stability of the cell, studied by holding the cell continuously at a potential of $1.0 \mathrm{~V}$ vs. $\mathrm{Hg} / \mathrm{HgO}$ electrode and monitoring the current at the temperature of $30^{\circ} \mathrm{C}$. The current was constant indicating the stability of the cell with added citric acid.

(a)

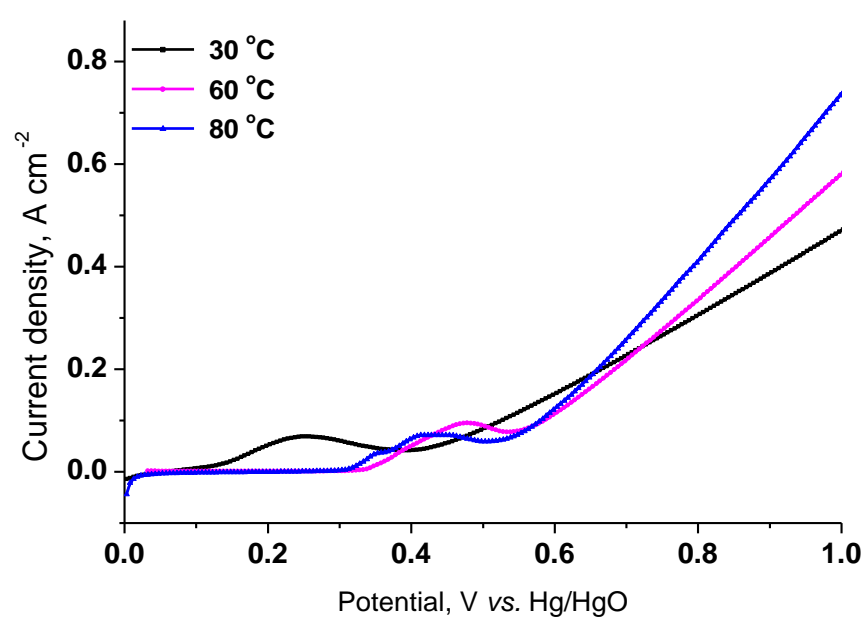

(b)

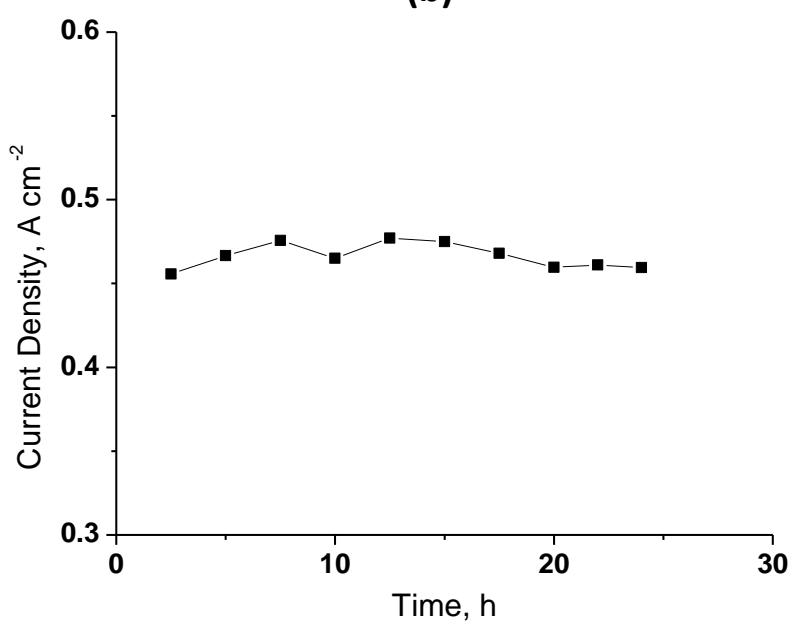

Figure 5.Effect of temperature on the addition of CA (0.2 wt. \%) in alkaline water electrolysis (a) and stability test with addition of $\mathrm{CA}(0.2 \%)$ at $1.0 \mathrm{~V}$ vs. $\mathrm{Hg} / \mathrm{HgO}$ at $30^{\circ} \mathrm{C}$ (b)

\section{SEM analysis}

Scanning electron microscopy (SEM) of the nickel anode was performed before and after ( $24 \mathrm{~h}$ of continuous operation) the electrolytic process with the addition of the CA in the electrolyte. The typical SEM images are presented in Fig. 6. The morphology of deposits before electrolysis are shown in Figure 6 (a) and (b). In these micrographs homogenous globular particles are seen. The surface of the electrodes is also divided by coarser cracks and channels. The cracks are likely to be filled with the electrolyte when dipped in the solution. This increases the surface area of the catalyst in contact with the electrolyte and leads to increase in current density. Further, efficiency may also be increased due to convective replenishment of the electrolyte due to gas evolution. The EDAX data of the nickel alloy electrodes prepared has a composition of nickel (55\%), zinc (30\%) and sulphur (15\%).

The morphology of deposits after addition of the CA during the electrolytic process is shown in Fig. 6 (c) and (d). The surface of the electrodes is characterized by the presence of flakes covering the electrodeposited layers. 


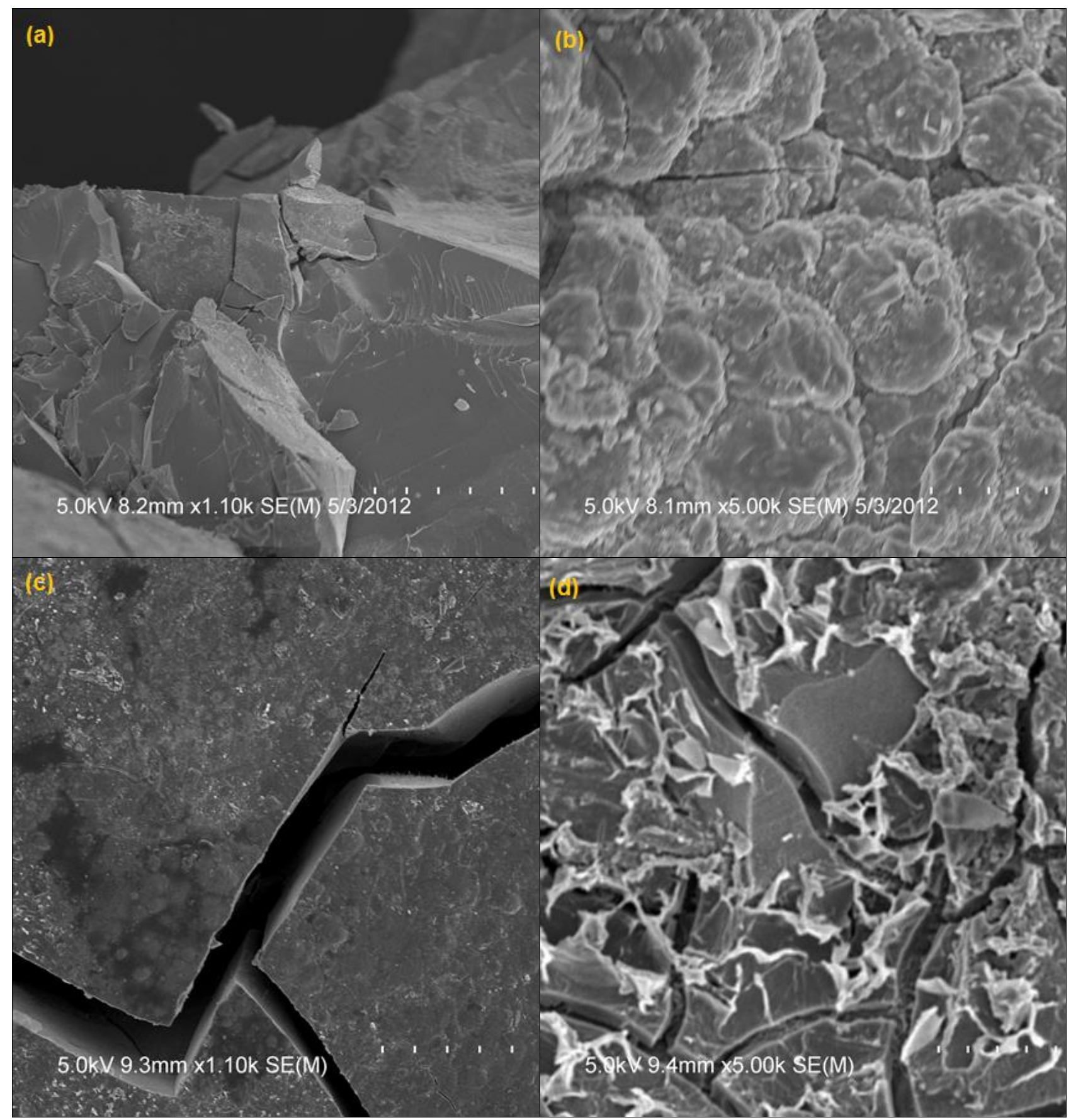

Figure 6. SEM Images of nickel alloy electrodes: (a) and (b) after electrolysis with $\mathrm{KOH}$,

(c) and (d) After electrolysis with $\mathrm{KOH}$ and $\mathrm{CA}$

The deposits appear to be interspersed on the surface of the electrode and make the surface appear rough. Thus, it is evident that the addition of CA in the electrolyte has resulted in the deposition of $\mathrm{Ni}$ metal particle on the surface during the electrolytic process. Thus, an increase in surface area and an increase in possible active centers are revealed in the SEM micrographs of the sample after electrolysis. The citric acid complexing agent thus acts as a bridge for the transfer of electrolyte on the surface of the electrode and the in situ metal deposits with their high surface area and catalytic activity improve the performance of the electrode for OER. These results compare well with the powder deposits of Fe-Ni observed by use of citric acid by Lačnjavec et al. [22] in their studies on electrodeposition of Fe-Ni from citrate electrolytes. 


\section{XRD analysis}

Figure 7 shows the XRD patterns of electrodeposited nickel electrodes before and after ( $24 \mathrm{~h}$ of continuous operation) electrolysis. The X-ray diffraction pattern of the before electrolysis sample has a broad peak around $44^{\circ}$ corresponding to (111) position of Ni. Due to the high concentration of nickel, the intensity of these peaks is high and hence only these are seen. The $\mathrm{Zn}$ and S present are detected only by the EDAX analysis. In the after electrolysis curve the intensity of the nickel peak is very high and the peak is also very sharp. The average particle size was calculated using DebyeScherrer relation. The particle size of samples after and before electrolysis was found to be between 11 and $16 \mathrm{~nm}$ respectively. This may be explained by the deposition of the in situ Ni particles from the Ni citrate complex formed. Such in situ deposited particles may be responsible for the increased electrochemical activity shown in the OER reaction. It shows that the size of Ni deposit particles can be modified by the addition of citric acid. Similar observations of metal deposition have been reported from the solution by Nikolić et al.[14].

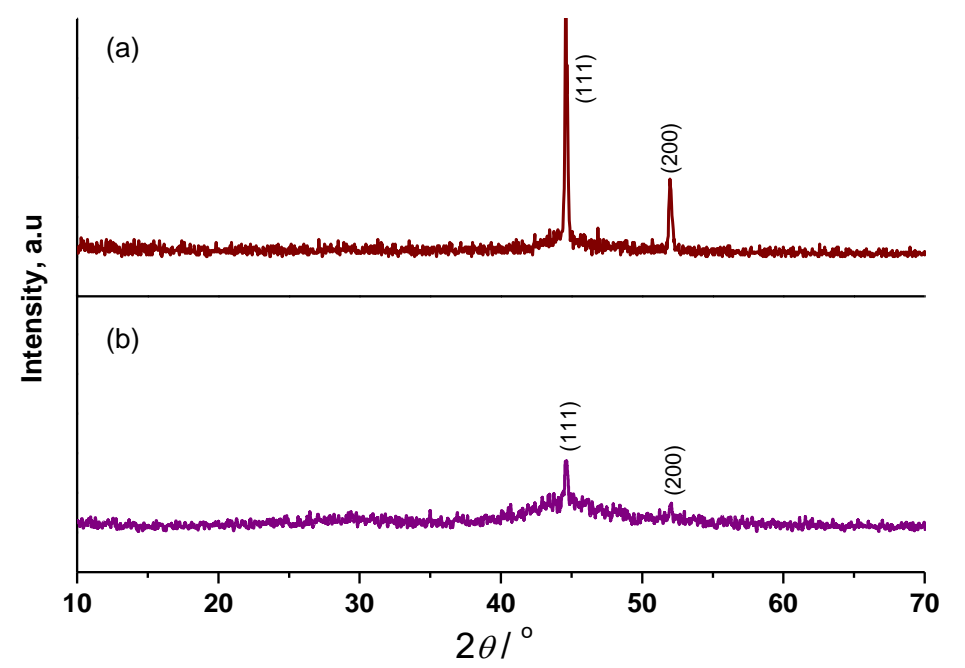

Figure 7. XRD patterns of nickel surface: (a) after electrolysis; (b) before electrolysis

The addition of $0.2 \mathrm{wt}$. \% citric acid to the standard electrolyte as a complexing agent thus decreases the energy consumption during electrolysis of water. The addition resulted in the in situ deposition of Ni on the surface (as shown in SEM figures). The improved performance suggests that an extremely active surface center is created to improve the catalytic activity of the electrode. Further the formation of the nickel citrate complex may improve the wettability of the electrode and may act as a bridge for ion transfer between the electrolyte and the metal surface [23].

\section{Conclusions}

The results presented help in concluding that a deposit formed in-situ during the electrolytic process by using a complexing agent such as CA in the electrolytic solution is extremely active. An increase in the current density of about $25 \%$ resulted at a temperature of $30^{\circ} \mathrm{C}$ in the presence of 0.2 wt. \% of $\mathrm{CA}$ at $1.0 \mathrm{~V}$ vs. $\mathrm{Hg} / \mathrm{HgO}$. The CA distributed throughout the nickel matrix as a complex created more organized transfer channels to produce high surface area electrodes for alkaline water electrolysis. SEM and XRD figures obtained after electrolysis confirm the deposition of the metal. This form of deposit is very active and improves the catalytic activity of the electrode. Improvement may also be explained due to increase in wettability and the bridging ability of the complexing agent to transfer ions between the electrolyte and metal surfaces. Thus, through simple processing, high 
current density and good efficiency can be obtained. We believe this type of complexing agent deserves further investigation and is a good candidate for use in alkaline water electrolysis.

Acknowledgement: The authors would like to thank Director, $A R C l$ for his constant encouragement and support and Department of Science and Technology (DST), Government of India for financial assistance. S. Seetharaman thanks ARCI for the Senior ARCI fellowship under which this work was carried out.

\section{References}

[1] E. Rasten, G. Hagen, R. Tunold, Electrochim. Acta 48 (2003) 3945-3952

[2] P. Millet, D. Dragoe, S. Grigoriev, V. Fateev, C. Etievant, Int. J. Hydrogen Energ. 34 (2009) 4974-4982

[3] S. P. S. Badwal, S. Giddey, F. T. Ciacchi, lonics 12(2006)7-14

[4] J. Panek, A. Budniok, Surf. Interface Anal.40 (2008) 237-241

[5] A. A. Kamnev, B. B. Ezhov, V. Rusanov, V. Angelov, Surf. Interface Anal. 19(1992) 577-580

[6] P. W. T. Lu, S. Srinivasan, J. Electrochem. Soc. 125 (1978) 1416-1422

[7] G. Zhang, Y. Qiu, X. Yang, X. X. Li, H. Pan, Desalin. Water Treat. 56 (2015) 905-911

[8] G. Sheela, M. Pushpavanam, S. Pushpavanam, Int. J. Hydrogen Energ. 27 (2002) 627-633

[9] M. S. Sadovnikova, V. M. Belikov, Russ. Chem. Rev. 47 (1978) 199-212

[10] B. H. Chen, L. Hong, Y. Ma, T. M. Ko, Ind. Eng. Chem. Res. 41 (2002) 2668-2678

[11] V. C. Kieling, Surf. Coat. Tech. 96 (1997) 135-139

[12] Q. Mao, L. Zhang, D. Huang, D. Wang, Y. Huang, H. Xu, H. Cao, Z. Mao, Surf. Interface Anal. 43 (2011) 903-912

[13] I. G. Casella, M. Gatta, J. Electroanal. Chem. 534 (2002) 31-38

[14] V. M. Nikolić, G. S. Tasić, A. D. Maksić, D. P.Šaponjić, S. M. Miulović, M. P. M. Kaninshi, Int. J. Hydrogen Energ. 35 (2010) 12369-12373

[15] M. P. M. Kaninski, A. D. Maksić, D. L. Stojić, S. C. Miljanić, J. Power Sour. 131 (2004)107-111

[16] S. M. Miulović, S. L. Maslovera, M. M.Šeović, B. B. Raduk, M. P. M. Kaninski, Int. J. Hydrogen Energ. 37 (2012) 16770-71675

[17] E. Gomez, S. Pane, E. Valles, Electrochim. Acta 51(2005) 146-153

[18] A. Afshat, A. G. Dolati, M. Ghorbani, Mater. Chem. Phys. 77 (2003) 352-358

[19] S. Seetharaman, R. Balaji, K. Ramya, K. S. Dhathathreyan, M. Velan, Ionics 20 (2014) 713720

[20] A. Seghiover, J. Chevalet, A. Barhoun, F. Lantelme, J. Electroanal. Chem. 442(1998)113-123.

[21] M. C. Biesinger, B. P. Payne, L. W. M. Lau, A. Gerson, R. S. C. Smart, Surf. Interface Anal. 41 (2009) 324-332

[22] U. Lačnjevac, B. M. Jović, V. D. Jović, Electrochim. Acta 55 (2009) 535-543

[23] O. Gyliene, J. Aikaite, O. Nivinskiene, J. Hazard. Mater. 109 (2004) 105-111.

2016 by the authors; licensee IAPC, Zagreb, Croatia. This article is an open-access article distributed under the terms and conditions of the Creative Commons Attribution license (http://creativecommons.org/licenses/by/4.0/) 